\title{
Genetic diversity of the blue land crab Cardisoma guanhumi (Latreille 1825) in the Alvarado Lagoon System in Veracruz, gulf coast of Mexico
}

\author{
José Francisco Rendón-Hernández ${ }^{1}$, Carlos Iván Pérez-Rostro² ${ }^{2}$ Ricardo González-Trujillo ${ }^{3}$ \\ Guadalupe Fabiola Arcos-Ortega ${ }^{4}$, María de Lourdes Jiménez-Badillo ${ }^{1}$ \& Gabriela Galindo-Cortes ${ }^{1}$ \\ ${ }^{1}$ Instituto de Ciencias Marinas y Pesquerías, Universidad Veracruzana, Boca del Río, Veracruz, México \\ ${ }^{2}$ Laboratorio de Mejoramiento Genético y Producción Acuícola, Instituto Tecnológico de Boca \\ del Río, Boca del Río, Veracruz, México \\ ${ }^{3}$ Centro de Investigación para los Recursos Naturales, Antigua Normal Rural de Salaices \\ López, Chihuahua, México \\ ${ }^{4}$ Departamento de Acuacultura, Laboratorio de Inmuno-genómica Marina, Centro de Investigaciones \\ Biológicas del Noroeste, La Paz, Baja California Sur, México \\ Corresponding author: María de Lourdes Jiménez-Badillo (ljimenez@uv.mx)
}

\begin{abstract}
In the Alvarado Lagoon System (ALS) in south-central Veracruz on Mexico's gulf coast, the blue land crab, Cardisoma guanhumi, a semi-terrestrial crustacean species, represents an important fishery resource, but one that is subject to overexploitation and habitat destruction. Identifying genetic diversity and the genetic unit are required to establish efficient conservation strategies. The present study's goal was to assess the genetic structure and degree of genetic diversity of $C$. guanhumi populations along the ALS. A fragment of the D-loop region of the mtDNA $(750 \mathrm{bp})$ and a partial sequence of the COI gene $(580 \mathrm{pb})$ was sequenced for 120 specimens collected at four sites in the ALS. Genetic diversity indices were estimated for each marker. The study sites' gene flow was estimated, as was the effective population size and the mutational rate for each locality. A haplotype network was built to estimate the gene genealogies of the populations. A Tajima's neutrality test, $F u$ tests, and mismatch analysis were performed to detect demographic expansion. Results show that this $C$. guanhumi population has high genetic diversity with a large gene flow among the localities studied and expanded during the recent evolutionary past. All haplotypes from both markers are novel for the species, according to the NCBI GenBank. The high genetic diversity and genetic connectivity among sites suggests that the size of blue crab populations in the ALS has not been drastically affected by past exploitation. Finally, management strategies are proposed to protect the species.
\end{abstract}

Keywords: Cardisoma guanhumi; land crab; genetic diversity; COI; D-loop region mtDNA; Alvarado Lagoon System, Mexico

\section{INTRODUCTION}

The blue land crab, Cardisoma guanhumi (Latreille 1828), a member of the Gecarcinidae family, is a semiterrestrial species widely-distributed along the Atlantic coast of North America, from Florida to the Bahamas, including from Mexico's gulf coast to southern Brazil (Amaral et al. 2015) and the Bermuda Islands (Hartnoll 1988, Spivak 1997, Hostetler et al. 2003). In Mexico, as in other countries, this crab is a food source and an important fishery resource (Bozada \& Chávez 1986, Oliva-Rivera 2005, DOF 2012). However, high demand has led to overharvesting, causing a decline in population size (DOF 2008). Additionally, predation and habitat destruction affect this species' life-cycle by causing mortality during the larval stage (DOF 2008, Silva et al. 2014). C. guanhumi populations have not been evaluated under the IUCN red list and do not have special status on the US Federal List or the CITES appendix. However, Florida's Fish and Wildlife Conservation Commission classifies them as "biologically vulnerable" (FWC 2017), while in Brazil they are described as "threatened, over-exploited, or threatened with overexploitation" (DOU 2004). Although the blue

Corresponding editor: José Gallardo 
land crab is caught along Mexico's gulf coast (DOF 2012), no current information is available on its population status (DOF 2010).

Since 1998, catches of C. guanhumi in Alvarado Veracruz, Mexico, have reflected a constant decline in this species' population, so its status is now classified as "threatened with overexploitation" (DOF 2008). In response, and to obtain data that will establish efficient management and conservation strategies, the Mexican government has developed a series of initiatives to evaluate this resource, including genetic aspects. There are reports that $C$. guanhumi larvae have a plasticity that allows them to adapt to wide temperature and salinity conditions (Costlow \& Bookhout 1968). It is also well-known that $C$. guanhumi presents the dispersion of planktonic stages as the primary mechanism of colonization and connections among established populations (Amaral et al. 2015). This mechanism would lead to the mixing of populations that share the same gene pool (Ayre et al. 1997); however, some molecular analyses performed in $C$. guanhumi have shown a marked genetic structure (Фst $=0.488 ; P=0.00)($ Amaral et al. 2015) that contradicts this expectation of high connectivity. In the case of the C. guanhumi populations in the ALS, it may be that the effective population sizes at distinct localities differ and are small as a consequence of overexploitation, which would make populations susceptible to greater drift that favors genetic differentiation. This scenario could be added to the presence of diverse ecological conditions throughout the distribution area of this species in the ALS that could determine the natural selection of different genotypes, thus increasing differentiation. Diverse genetic units would make it necessary to propose specific management strategies for some ALS sites. Given this scenario, the present study's goal was to characterize the genetic diversity and genetic structure of $C$. guanhumi populations along the ALS and contribute to establishing suitable conservation strategies.

\section{MATERIALS AND METHODS}

\section{Study area and data collection}

The ALS is a lagoon-estuarine system composed of brackish coastal lagoons. This study focuses on Alvarado, Buen País, and Camaronera lagoons (Portilla-Ochoa et al. 2003). It is a type I, internal barrier platform coastal lagoon (Lankford 1977). The ALS connects to the Gulf of Mexico through two channels, one natural in Alvarado Lagoon $(\sim 1000 \mathrm{~m}$ wide, $8 \mathrm{~m}$ deep), the other artificial in Camaronera Lagoon ( $2 \mathrm{~m}$ wide, $1 \mathrm{~m}$ deep). A total of 120 Cardisoma guanhumi adults $(50-120 \mathrm{~mm}$, carapace width) were collected between January and April 2015 at four sites:

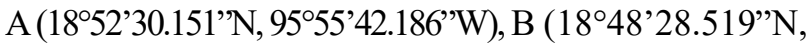

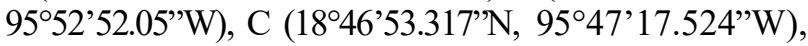
and D (18 43'46.732'N, 95'43'48.137'W) (Fig. 1). Sandy beaches different distances between study sites and other estuaries, varied from $5-25 \mathrm{~km}$.

\section{Sample preparation and DNA extraction}

One pereiopod was removed from each specimen and preserved in $96 \%$ ethanol; then, the organisms were returned to their natural habitat. Later, a $1 \mathrm{~cm}^{-3}$ fragment of muscle tissue from each pereiopod was prepared by first removing the cuticle to decrease pigments and chitin-like compounds that could interfere with tissue preservation and DNA extraction. Tissue samples were immersed in 96\% ethanol and stored $\left(\right.$ at $\left.-20^{\circ} \mathrm{C}\right)$ for further analysis.

DNA extraction was performed using the saltingout method described by Aljanabi \& Martinez (1997). DNA quality and integrity were confirmed by agarose gel electrophoresis (2\%) under staining with GelRed $\left(0.5 \mu \mathrm{g} \mathrm{mL}^{-1}\right)$, with X174/Hae III (Promega) as the molecular weight marker $(1358,1078,872,603,310$, $281,271,234,194,118$ and 72 bp). The DNA concentration of each sample was calculated using a Nanodrop 2000c (ThermoScientific ${ }^{\circledR}$ ). Individual DNA concentrations were standardized at $20 \mathrm{ng} \mu \mathrm{L}^{-1}$ before performing PCR.

\section{PCR amplification}

The primers ${ }_{12} \mathrm{SUCAF}_{3}\left(5^{\prime}\right.$-CCA GTA NRC CTA CTA TGT TAC GAC TTA T-3') and ILEUCAR 3 (5'GCT AYC CTT TTA AAT CAG GCA C-3') were used to amplify a $\approx 750 \mathrm{bp}$ fragment from the $\mathrm{D}$-loop region of the mtDNA (Oliveira-Neto et al. 2008). The universal DNA primers LCO1490 (5'-GGT CAA CAA ATC ATA AAG ATA TTG g-3') and HC02198 (5'TAA ACT TCA GGG TGA CCA AAA AAT CA-3') were used to amplify a $\approx 580 \mathrm{bp}$ fragment from the COI gene (Folmer et al. 1994). The synthesis of primers was performed in Macrogen Inc. (Seoul, Korea).

PCR was conducted in a Veriti $^{\mathrm{TM}}$ thermocycler (Applied Biosystems). Average melting temperatures (Tm) and primer concentrations were standardized in a gradient PCR to standardize, as well, the Tm of each primer pair until the expected band size was obtained. Each 18- $\mu$ PCR solution had the following final concentrations: $\mathrm{MgCl}_{2}(1.9 \mathrm{mM})$, dNTPs $(0.6 \mathrm{mM})$, Taq polymerase $\left(0.1 \mathrm{U} \mu \mathrm{L}^{-1}\right)$, buffer $(0.9 \mathrm{x})$, each primer $(1.0 \mathrm{mM})$, betaine $(1 \mathrm{M})$, genomic DNA $\left(1 \mathrm{ng} \mathrm{mL}^{-1}\right)$, and $11 \mu \mathrm{L}$ of $\mathrm{H}_{2} \mathrm{O}$. The thermocycling settings for the COI gene included the following steps: $96^{\circ} \mathrm{C}$ for $3 \mathrm{~min}$, followed by five cycles at $94^{\circ} \mathrm{C}$ for $30 \mathrm{~s}, 45^{\circ} \mathrm{C}$ for $45 \mathrm{~s}$, 


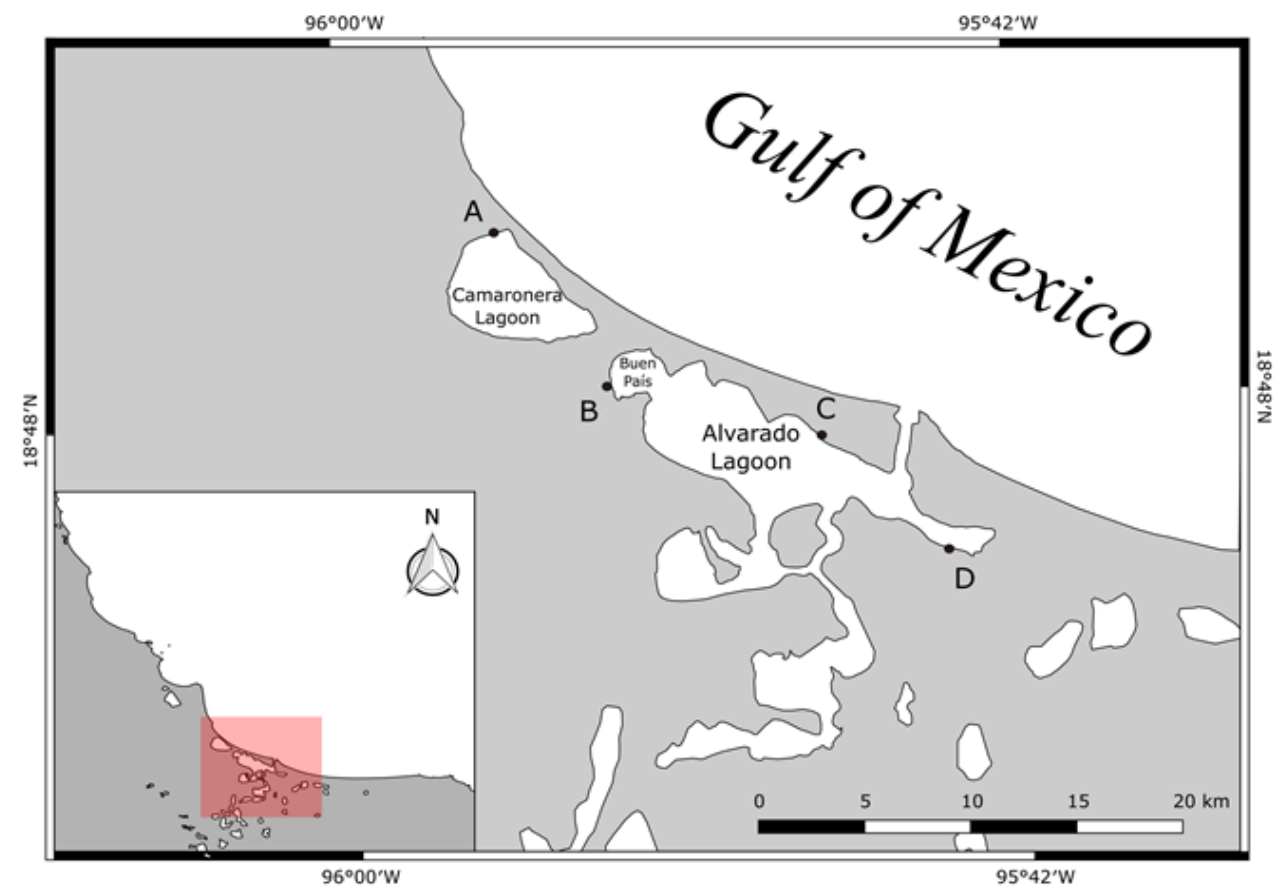

Figure 1. A, B, C, D collection sites of Cardisoma guanhumi specimens, along the Alvarado Lagoon System (ALS), Veracruz, Mexico.

and $72^{\circ} \mathrm{C}$ for $60 \mathrm{~s}$, followed by 35 cycles at $94^{\circ} \mathrm{C}$ for 30 $\mathrm{s}, 51^{\circ} \mathrm{C}$ for $45 \mathrm{~s}, 72^{\circ} \mathrm{C}$ for $60 \mathrm{~s}$, and a final extension at $72^{\circ} \mathrm{C}$ for $5 \mathrm{~min}$. The thermocycling settings for the mtDNA's D-loop region proceeded as follows: $96^{\circ} \mathrm{C}$ for $3 \mathrm{~min}$, followed by 35 cycles at $94^{\circ} \mathrm{C}$ for $60 \mathrm{~s}, 56^{\circ} \mathrm{C}$ for $60 \mathrm{~s}$, and $72^{\circ} \mathrm{C}$ for $60 \mathrm{~s}$, and a final extension at $72^{\circ} \mathrm{C}$ for $10 \mathrm{~min}$. Amplified fragments from both genes were visualized by agarose gel electrophoresis (2\%) stained with GelRed $\left(10 \mu \mathrm{g} \mu \mathrm{L}^{-1}\right)$, using phiX174/Hae III (Promega) as the molecular weight marker. Electrophoresis images were obtained in a UV transilluminator Imager $^{\circledR}$, Gel-Pro visualized, and HP AlphaImager $^{\circledR}$ System. The PCR products were sequenced on both strands by Macrogen Inc. (Seoul, Korea) using the PCR primers.

\section{Data analysis}

Chromatograms of the forward and reverse DNA sequences from both genes of each individual (COI and D-loop region of the mtDNA) were edited manually in Sequencer 5.4.6.software (Gene Codes Corp., Ann Arbor, MI). Homologous nucleotide sequences from all samples were aligned in PhyDE (Müller et al. 2008). Unique haplotypes were identified using DnaSP v5 (Librado \& Rozas 2009). Genetic diversity indices (nucleotide $(\pi)$ and haplotype diversity $(H d)$ ) were estimated for each marker using Fisher's exact test from the same software package (DnaSP v5, Librado \& Rozas 2009). Genetic differentiation among the ALS study sites was tested by a hierarchical analysis of molecular variance (AMOVA). Simultaneously, population pairwise $\Phi$ st values (analogous to $F$ st values) between populations were calculated in Arlequin 3.5 (Excoffier \& Lischer 2010), using 10,000 random permutations.

Estimates of gene flow among the study sites were carried out based on Nei's formula (1987): Nm = (1- Fst / 2 Fst), where $\mathrm{Nm}$ is the effective number of migrants between populations by generation. The $\Phi$ st values were used to make estimates, instead of $F$ st. The values of the effective population size $(\mathrm{Ne})$ were also calculated. The $\mathrm{Nm}$ and $\mathrm{Ne}$ values were estimated through maximum likelihood using Markov Chain Monte Carlo (MCMC) simulations in the Migrate v.2.1.3 program (Beerli 2004). This method applies coalescence theory to estimate asymmetric migration rates among populations, considering historical mutations, genealogy, and sub-populations' diverse sizes. The sequences obtained from the mtDNA of the COI and D-loop region of each locality were used independently to perform the $\mathrm{Nm}$ simulations using this approach. In the MCMC analysis strategy, a series of 10 short (5000 calculated trees) and three long chains $(50,000$ calculated trees) were used. The first 10,000 trees were ignored. Ten simulations were performed to evaluate the consistency of results. The $\mathrm{Ne}$ values obtained from the ten simulations of the Migrate program were then averaged for each location. These 
values were represented by $\theta=\mathrm{Ne} . \mu$ (product of effective population size and mutational rate) for each site.

A statistical parsimony criterion was applied to estimate gene genealogies among populations to build a haplotype network for each marker using PopART (Clement et al. 2002). The sample size for this test was smaller for each marker. To detect demographic expansion, we performed a Tajima's neutrality test (Tajima 1989), $F u$ tests, and mismatch analysis in DnaSP v5 (Librado \& Rozas 2009).

The DNA sequences from the COI and D-loop region mtDNA markers were registered in the National Center for Biotechnology Information (NCBI) GenBank database.

\section{RESULTS}

\section{Genetic diversity analysis}

We amplified 70 partial sequences of the COI gene ( 580 base pairs) and 58 fragments ( $115 \mathrm{bp}$ ) from the Dloop region mtDNA. The analysis of sequences from both markers indicated high genetic diversity at all study sites in the ALS (Table 1). For the COI gene, we detected 27 haplotypes (Fig. 2, Tables 1, S1), where $\mathrm{Cg}$-COI-H4 $(\mathrm{n}=15$, relative frequency $=0.2)$ and $\mathrm{Cg}$ $\mathrm{COI}-\mathrm{H} 3(\mathrm{n}=8$, relative frequency $=0.11)$ were the most frequent ones and displayed a broad distribution (Fig. 2). Most of the COI haplotypes' frequency values were below 3 , and the number of unique haplotypes was 15 (Table S1). For the D-loop region mtDNA, we detected 17 haplotypes (Fig. 3, Table 1). The haplotypes most often observed, with broad distributions (Fig. 3, Table S2), were Cg-D-loop-HI (n $=22, \mathrm{RF}=0.37), C g-D$-loop $-H 2(\mathrm{n}=4, \mathrm{RF}=0.06), D$ loop-H6 ( $\mathrm{n}=4, \mathrm{RF}=0.06), C g$-D-loop-H3 (n = 6, RF $=0.1)$ and $C g$-D-loop-H1O $(\mathrm{n}=7, \mathrm{RF}=0.12)$. There were nine unique haplotypes, and the frequency values for seven others were below four. Table 1 presents the genetic diversity indices (average \pm standard deviation), haplotype diversity (Hd), and nucleotide diversity $(\pi)$. For the D-loop region mtDNA, the highest nucleotide diversity value was obtained in population A ( $\pi=0.0240 \pm 0.00359)$, and the lowest in population $\mathrm{D}(\pi=0.0192 \pm 0.0035)$. For the COI gene, the highest nucleotide diversity value was obtained in population $\mathrm{B}(\pi=0.00668 \pm 0.00131)$, and the lowest in population A $(\pi=0.00479 \pm 0.00091)$. All haplotypes from both markers submitted to the NCBI database proved to be novel for this species. The GenBank access numbers are shown in Tables S1-S2.

\section{Population structure analysis}

The AMOVA and population pairwise analysis based on haplotype frequencies from the four study sites for the COI and D-loop region mtDNA of Cardisoma guanhumi did not reveal population genetic structuring at sites, according to the $\Phi$ st values, which differed significantly from zero (Table 2). Most of the genetic variation occurred within the populations (Tables 3-4). The Nm results showed high genetic flow (Table 5), which implies that the $C$. guanhumi populations in the ALS behave like one large population with a massive flow of migrants among the localities studied. The gene flow between sites $\mathrm{A}$ and $\mathrm{B}$ was the most extensive and was consistent (C) in all 10 simulations. The rest of the localities obtained low levels of gene flow. Some scenarios were not consistent (NC) (Table 5). The highest $\theta$ value $(\mathrm{Ne} . \mu)$ was obtained at site $\mathrm{B}$, while localities $\mathrm{A}, \mathrm{C}$, and $\mathrm{D}$ all presented similar values.

The haplotype network based on comparing all sequences from the four study sites evidenced a highly heterogeneous pattern for both COI and D-loop region mtDNA markers, no correspondence between haplotypes and geography (Figs. 4-5). Several private haplotypes were detected for both markers, but no weak dominance of any haplotype (Tables S1-S2). Although the Tajima test was not significant for COI, mismatch pairwise comparisons suggest population expansion (Fig. 6). These results were supported by a significant $F u$ test $(\mathrm{D}=-2.39, P<0.05)$. For the D-loop region mtDNA marker, the Tajima $(D=-1.28)$ and $F u(D=$ -1.97) tests did not show significant differences $(P>$ $0.05)$.

\section{DISCUSSION}

The blue land crab populations (Cardisoma guanhumi) from the ALS have high genetic diversity reflected in both the COI and D-loop region mtDNA markers. These results concur with previous reports on other populations of blue land crabs in Brazil (Oliveira-Neto et al. 2008) and the west-central Atlantic region (Amaral et al. 2015), and studies of other crustacean species (McMillen-Jackson \& Bert 2004, Diniz et al. 2005, Cassone \& Boulding 2006, Naro-Maciel et al. 2011).

The high gene diversity of the blue land crab populations in the ALS could be explained by the recent demographic expansion evidenced in this study, which is consistent with reports indicating that current population growth is a factor that has produced high genetic diversity (Frankham et al. 2002, McMillenJackson \& Bert 2004). After population expansion, the number of new alleles is greater than those that can be lost by genetic drift (Avise et al. 1984). Another factor responsible for high diversity is an elevated mutation rate (Grant \& Bowen 1998, Avise 2004), as was observed in the COI and D-loop region mtDNA frag- 
Table 1. Genetic diversity indices obtained using COI and D-loop region mtDNA sequences in ALS Cardisoma guanhumi populations. Pop: population source, n: sample size, H: haplotype richness, Hd: gene diversity (SD: standard deviation), $\pi$ nucleotide diversity, bp: pair base size, ALS: Alvarado Lagoon System, Veracruz, Mexico.

\begin{tabular}{lcccccc}
\hline Gene & Pop & $\mathrm{n}$ & $\mathrm{H}$ & $\mathrm{Hd}(\mathrm{SD})$ & $\pi(\mathrm{SD})$ & $\mathrm{bp}$ \\
\hline & All & 70 & 27 & $0.923 \pm 0.018$ & $0.00577 \pm 0.00056$ & 580 \\
COI & $\mathrm{A}$ & 15 & 11 & $0.943 \pm 0.045$ & $0.00479 \pm 0.00091$ & 580 \\
& $\mathrm{~B}$ & 16 & 10 & $0.917 \pm 0.049$ & $0.00668 \pm 0.00131$ & 580 \\
& $\mathrm{C}$ & 19 & 13 & $0.924 \pm 0.048$ & $0.00643 \pm 0.00102$ & 580 \\
& $\mathrm{D}$ & 20 & 14 & $0.958 \pm 0.028$ & $0.00552 \pm 0.00100$ & 580 \\
\hline \multirow{4}{*}{ D-loop región } & All & 58 & 17 & $0.829 \pm 0.042$ & $0.08200 \pm 0.00158$ & 115 \\
mtDNA & $\mathrm{A}$ & 15 & 9 & $0.848 \pm 0.088$ & $0.02403 \pm 0.00359$ & 115 \\
& $\mathrm{~B}$ & 10 & 6 & $0.889 \pm 0.075$ & $0.02370 \pm 0.00298$ & 115 \\
& $\mathrm{C}$ & 19 & 10 & $0.825 \pm 0.084$ & $0.02160 \pm 0.00327$ & 115 \\
& $\mathrm{D}$ & 14 & 8 & $0.868 \pm 0.076$ & $0.01929 \pm 0.00358$ & 115 \\
\hline
\end{tabular}

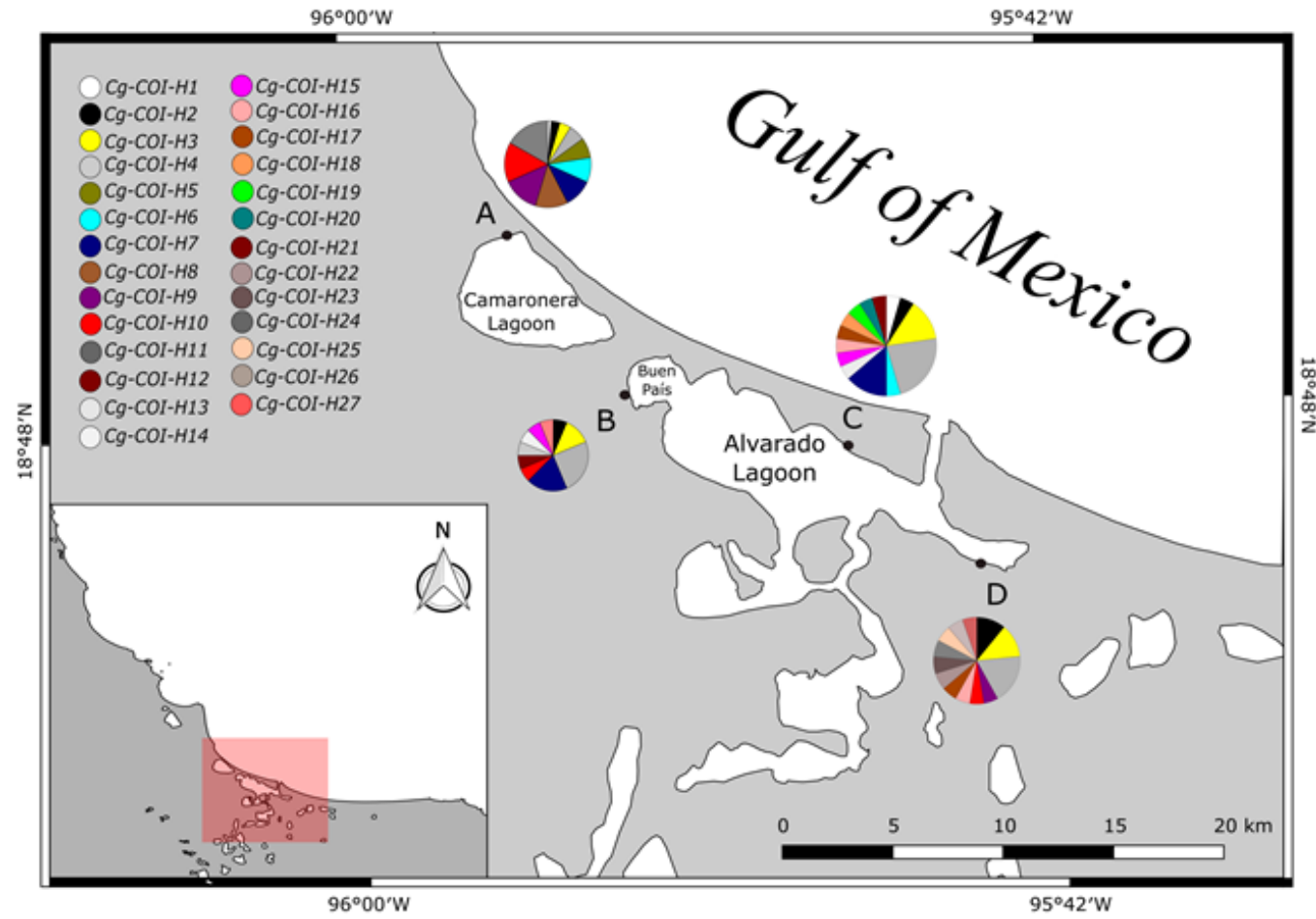

Figure 2. Haplotype frequency for Cardisoma guanhumi COI gene, in the sampled localities along the Alvarado Lagoon System (ALS), Veracruz, Mexico. Colors indicate haplotype frequency in each population (A, B, C, D). The size of the chart indicates the sample size.

ments analyzed herein. These markers were useful for detecting high genetic variability in this species.

There was no evidence of genetic structuring in the C. guanhumi populations from the four locations studied in the ALS, according to the $\Phi$ st values and AMOVA analysis, which is consistent with reports on other C. guanhumi populations from adjacent areas (Oliveira-Neto et al. 2008, Amaral et al. 2015). This study's lack of genetic structure was supported by the parsimony criterion, which revealed that geographic criteria do not group haplotypes. The high number of private haplotypes detected at each site for both markers, the few steps between them, and the nondominant $m t$ DNA haplotypes in populations for COI support the hypothesis of recent population expansion.

The population size, genetic homogeneity, and high diversity observed in the ALS indicate that according to Kumar et al. (2012) and Yuhara et al. (2014), the blue 


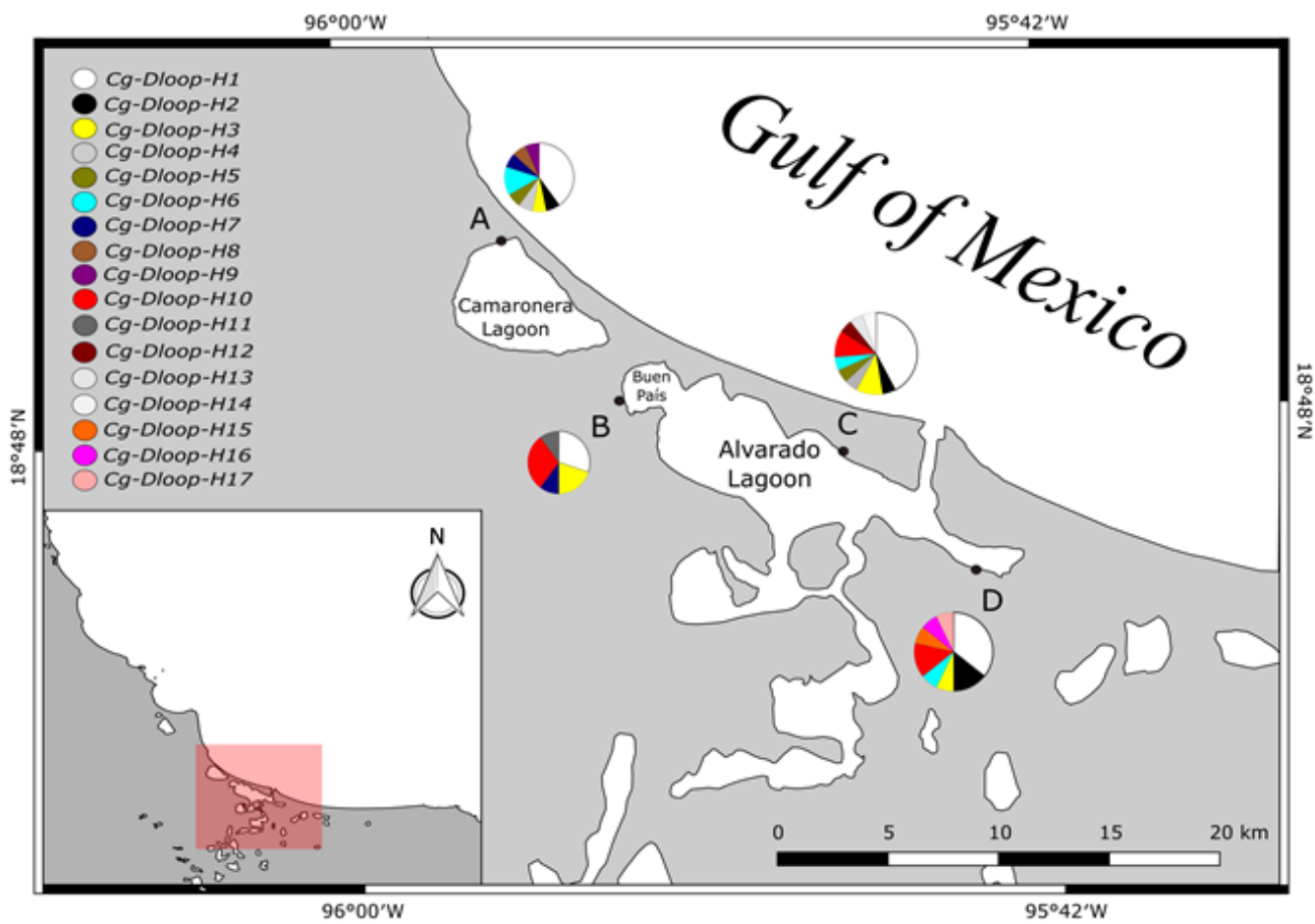

Figure 3. Haplotype frequency for Cardisoma guanhumi D-loop region mtDNA, in the localities, sampled along the Alvarado Lagoon System (ALS), Veracruz, Mexico. Colors indicate haplotype frequency in each population (A, B, C, D). The size of the chart shows the sample size.

Table 2. Estimates of population subdivision among ALS Cardisoma guanhumi populations using COI and D-loop region mtDNA sequences. Pairwise $\Phi$ st values (below the diagonal) and their corresponding significance test values $(P)$ (above the diagonal). Letters A,B,C,D indicate source populations. ALS: Alvarado Lagoon System, Veracruz, Mexico.

\begin{tabular}{|c|c|c|c|c|}
\hline & \multicolumn{4}{|c|}{ COI } \\
\hline & $\mathrm{A}$ & B & $\mathrm{C}$ & $\mathrm{D}$ \\
\hline A & - & 0.78 & 0.75 & 0.95 \\
\hline B & -0.0186 & - & 0.85 & 0.98 \\
\hline C & -0.0152 & -0.0211 & - & 0.58 \\
\hline D & -0.0257 & -0.0309 & -0.0072 & - \\
\hline & \multicolumn{4}{|c|}{ D-loop region mtDNA } \\
\hline & $\mathrm{A}$ & $\mathrm{B}$ & $\mathrm{C}$ & $\mathrm{D}$ \\
\hline A & - & 0.28 & 0.97 & 0.85 \\
\hline B & 0.0161 & - & 0.54 & 0.66 \\
\hline C & -0.0358 & -0.0158 & - & 0.96 \\
\hline D & -0.0294 & 0.0249 & -0.0370 & - \\
\hline
\end{tabular}

land crab has a meta-population structure characteristic of ocean crustacean species (McMillen-Jackson \& Bert 2004, Cassone \& Boulding 2006, Mims et al. 2016).

The genetic flow among crab populations is accomplished by dispersal of larvae (Oliveira-Neto et al. 2008), a phenomenon influenced by the oceanic system (gyres, local gyres, coastal currents) and differences in salinity and temperature of adjacent estuarine systems (McConaugha 1992, Sánchez \& Soto 1993, Manzanilla-Dominguez \& Gasca 2004), which can function as connectors between isolated populations or as barriers preventing gene flow between them. Thus, causing differences in genetic structure within and between populations (Bilton et al. 2002), as has been reported previously for $C$. guanhumi in the west-central Atlantic area (Amaral et al. 2015).

The distance between mangroves, the flow of water currents, and the form of the estuaries in the ALS all vary markedly (De la Lanza-Espino \& Montes 1999). Costal currents in the ALS are seasonal, running southward (counter-clockwise) from September to March, but northward (clockwise) from May to August (Zavala-Hidalgo et al. 2003), favoring larval transport as an important element in the mixing of populations. Moreover, it has been reported that blue land crab larvae can tolerate abrupt variations in salinity and temperature (Costlow \& Bookhout 1968). So, continuous migration among adjacent systems could be the leading cause of the high gene connectivity within these local ALS populations. 
Table 3. Analysis of molecular variance (AMOVA) among ALS populations of Cardisoma guanhumi based on COI sequences. ALS: Alvarado Lagoon System, Veracruz, Mexico. df: degrees of freedom.

\begin{tabular}{lcrccc}
\hline \multirow{2}{*}{ Source of variance } & \multicolumn{5}{c}{ COI } \\
\cline { 2 - 6 } & df & $\begin{array}{c}\text { Sum of } \\
\text { squares }\end{array}$ & $\begin{array}{c}\text { Variance } \\
\text { components }\end{array}$ & $\begin{array}{c}\text { Variation } \\
\text { percentage }\end{array}$ & $P$-value \\
\hline Among populations & 3 & 0.938 & -0.008 & -1.94 & 0.96 \\
Within populations & 66 & 30.891 & 0.468 & 101.94 & \\
Total & 69 & 31.829 & 0.459 & & \\
\hline
\end{tabular}

Table 4. Analysis of molecular variance (AMOVA) among ALS populations of Cardisoma guanhumi based on D-loop region mtDNA sequences. ALS: Alvarado Lagoon System, Veracruz, Mexico. df: degrees of freedom.

\begin{tabular}{lccccc}
\hline \multirow{3}{*}{ Source of variance } & \multicolumn{5}{c}{ D-loop mtDNA } \\
\cline { 2 - 6 } & $\mathrm{df}$ & $\begin{array}{c}\text { Sum of } \\
\text { squares }\end{array}$ & $\begin{array}{c}\text { Variance } \\
\text { components }\end{array}$ & $\begin{array}{c}\text { Variation } \\
\text { percentage }\end{array}$ & $P$-value \\
\hline Among populations & 3 & 0.841 & -0.009 & -2.41 & 0.89 \\
Within populations & 54 & 22.79 & 0.422 & 102.41 & \\
Total & 57 & 23.63 & 0.412 & & \\
\hline
\end{tabular}

Table 5. Gene flow (Nm) between pairs of localities estimated from the values of $\Phi$ st (below the diagonal), results obtained from the MCMC simulations with the Migrate program (above the diagonal), and average effective population sizes (in the diagonal). Vectors represent the relative magnitude and direction of the gene flux (from i to $\mathrm{j}(\rightarrow)$ and from $\mathrm{j}$ to $\mathrm{i}(\leftarrow)$ ). C: consistent results between the 10 simulations, and NC: non-consistent results among the 10 simulations.

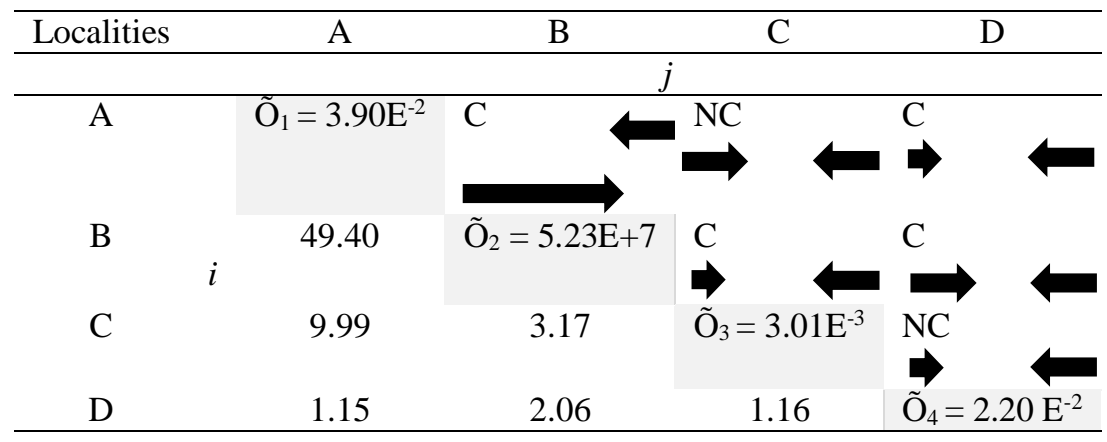

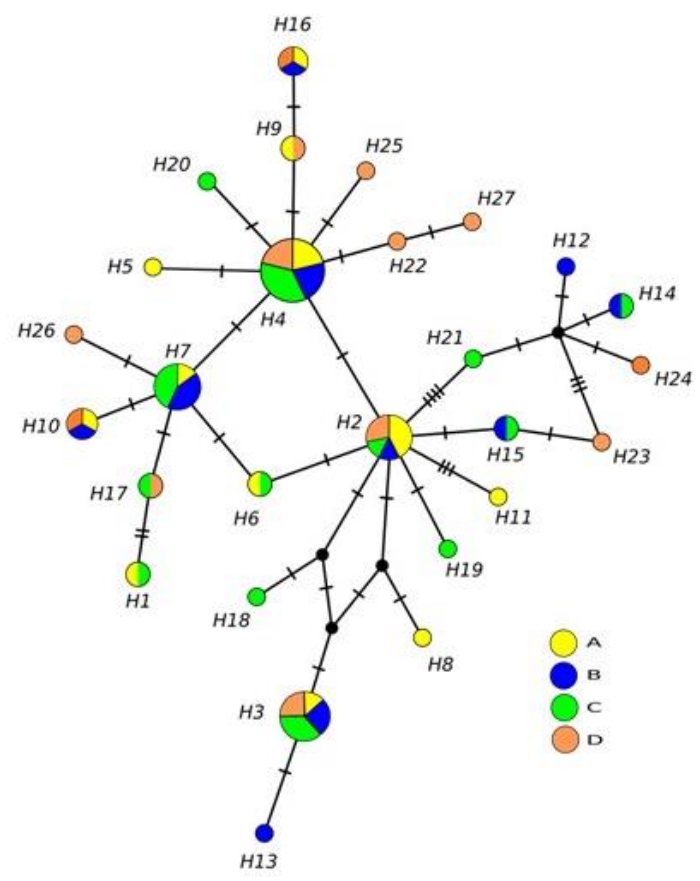

Figure 4. Haplotype network of Cardisoma guanhumi based on the comparison of all COI sequences under statistical parsimony criterion in the PopART program. Each circle represents a different haplotype, where $H$ corresponds to $\mathrm{Cg}$ - $\mathrm{COI}$ haplotypes. The circle's size fits each haplotype's frequency, and colors indicate four populations (A: yellow, B: blue, C: green, D: brown). Every hash mark represents one mutational step, and black dots indicate missing intermediate haplotypes.

The influence of the factors mentioned above on $C$. guanhumi larvae's dispersal potential in the ALS is still poorly understood. However, we do know that the larval dispersal of crustaceans with a planktonic larval stage, like C. guanhumi, is promoted by ocean currents (Candela et al. 2002, Shanks et al. 2003, Weersing \& Toonen 2009) that enable its migration capacity. For 


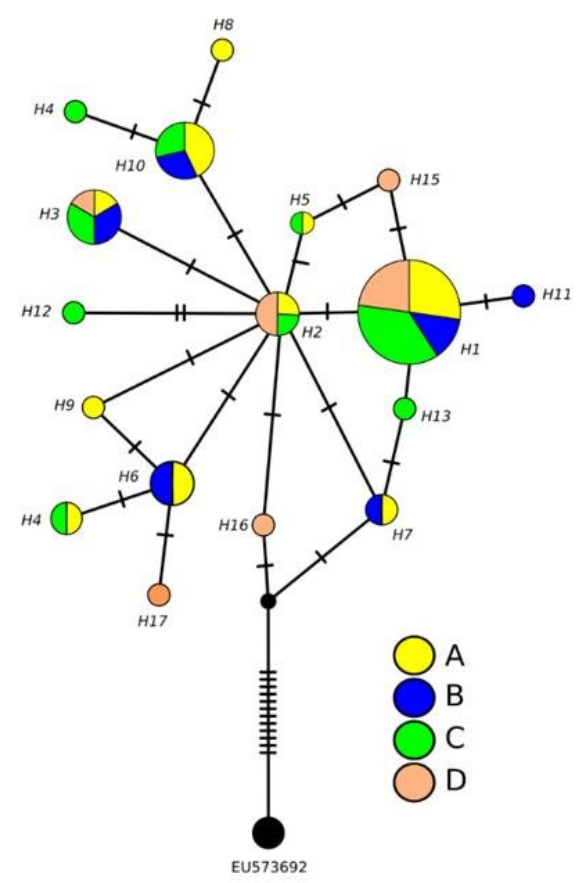

Figure 5. Haplotype network of Cardisoma guanhumi based on the comparison of all mitochondrial D-loop region sequences under statistical parsimony criterion in the PopART program. Each circle represents different haplotypes, where $H$ corresponds to $C g$ - $D$-loop haplotypes. The circle size corresponds to individuals' frequency with each haplotype, and colors indicate four populations (A: yellow, B: blue, C: green, D: brown). Every hash mark represents one mutational step, and black dots indicate missing intermediate haplotypes. EU573692 corresponds to the GenBank sequence from Brazil.

these reasons, crab populations studies have described that organisms can migrate among adjacent estuaries (Oliveira-Neto et al. 2008) but could present a specific genetic structure when populations are more geographically separated (Amaral et al. 2015).

Genetic continuity has been reported for blue land crab in populations separated by more than $5000 \mathrm{~km}$ in Brazil (Oliveira-Neto et al. 2008). Other studies, however, have detected genetic discontinuity in proximal populations $(2000 \mathrm{~km})$ in the west-central Atlantic and Caribbean regions (Amaral et al. 2015). Crab populations inhabiting areas adjacent to estuarine systems show gene flow and low genetic differentiation (Cowen \& Sponaugle 2009), as has been observed in Achygrapsus crassipes (Cassone \& Boulding 2006), Callinectes bellicosus (Pfeiler et al. 2005), and Cardisoma guanhumi (Oliveira-Neto et al. 2008). Other crab species, in contrast, such as Scylla serrata (Fratini \& Vannini 2002), Carcinus maenas (Roman \& Palumbi 2004), and Limulus polyphemus (Pierce et al. 2000), as well as various deep-sea crabs (Weinberg et al. 2003), have demonstrated high genetic differentiation among populations. Therefore, no one pattern

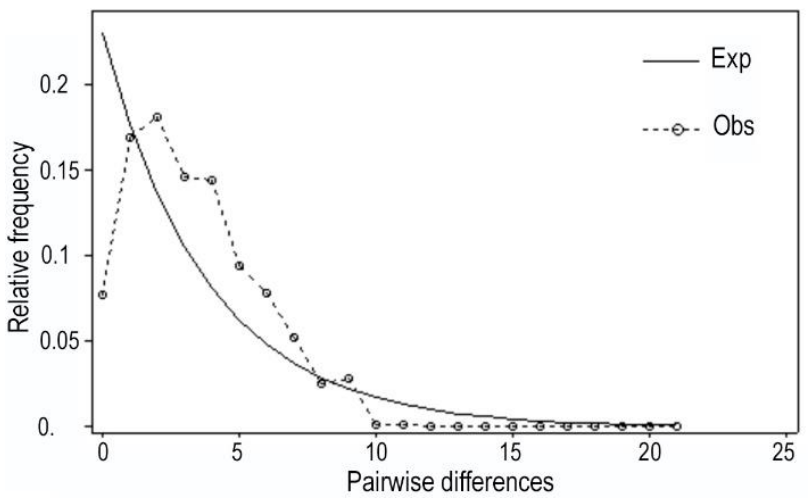

Figure 6. Mismatch distribution analysis for COI gen of Cardisoma guanhumi. Relative frequency in the ordinate gives the fraction of pairs that differ by the number of differences between pairs of DNA sequences (Rozas 2009). The line represents the null distribution; meanwhile, the dotted line represents observed distribution.

exists, and the possibilities are diverse depending on species, environmental conditions, and geographic region.

The populations of $C$. guanhumi in the ALS demonstrate high genetic diversity and genetic connectivity between lagoons. Population size, high diversity and genetic continuity suggests that blue crab populations in this area have not been drastically affected by past exploitation. Nevertheless, management strategies should be implemented to protect this species and prevent the loss of the rich genetic variation of its populations and the total number of organisms. The areas evaluated herein could be established as genetic reservoirs where capture is not allowed to achieve this. The current closure period could be extended from July to September to protect pregnant females and breeding.

\section{ACKNOWLEDGMENTS}

This study is part of the Doctoral Thesis in Ecology and Fisheries by the lead author in the Doctorado en Ecología y Pesquerías, Instituto de Ciencias Marinas y Pesquerías of the Universidad Veracruzana (ICIMAPUV). The author thanks CONACyT for the scholarship granted 367178 to carry out his studies. MLJB received partial support of project 194637 "Fortalecimiento de Redes Temáticas" from CONACYT and CIBNOR fiscal project AC.0.0. Anonymous reviewers helped improve an earlier version of the manuscript.

\section{REFERENCES}

Aljanabi, S.M. \& Martinez, I. 1997. Universal and rapid salt-extraction of high-quality genomic DNA for PCR- 
based techniques. Nucleic Acids Research, 25: 46924693. doi: 10.1093/nar/25.22.4692

Amaral, M.R.X., Albrecht, M., Mckinley, A.S., De Carvalho, A.M.F., Cavalcante-De Sousa, S. \& Diniz, F.M. 2015. Mitochondrial DNA. Variation reveals a sharp genetic break within the distribution of the blue land crab Cardisoma guanhumi in the Western Central Atlantic. Molecules, 20: 15158-15174. doi: 10.3390/ molecules200815158

Avise, J.C., Bermingham, E., Kessler, L.G. \& Saunders, N.C. 1984. Characterization of mitochondrial D.N.A. variability in a hybrid swarm between subspecies of bluegill sunfish (Lepomis macrochirus). Evolution, 38: 931-941. doi: 10.1111/j.1558-5646.984.tb00364.x

Avise, J.C. 2004. Molecular markers, natural history, and evolution. Sinauer Associates, Sunderland.

Ayre, D.J., Hughes, T.P. \& Standish, R.J. 1997. Genetic differentiation, reproductive mode, and gene flow in the brooding coral Pocillopora damicornis along the Great Barrier Reef, Australia. Marine Ecology Progress Series, 159: 175-187.

Beerli, P. 2004. MIGRATE: documentation and program, part of LAMARC, version 2.0. [https://evolution.genetics.washington.edu/lamarc/index.html]. Reviewed: September 10, 2019.

Bilton, D.T., Paula, J. \& Bishop, J.D.D. 2002. Dispersal, genetic differentiation, and speciation in estuarine organisms. Estuarine, Coastal and Shelf Science, 55: 937-952. doi: 10.1006/ecss.2002.1037

Bozada, L. \& Chávez, Z. 1986. La fauna acuática de la laguna del ostión. Centro de Ecodesarrollo. Universidad Veracruzana, 9: 42-26.

Candela, J., Sheinbaum, J., Ochoa, J., Badan, A. \& Leben, R. 2002. The potential vorticity flux through the Yucatan Channel and the Loop Current in the Gulf of Mexico. Geophysical Research Letters, 29: 2059. doi: 10.1029/2002GL015587

Cassone, B.J. \& Boulding, E.G. 2006. Genetic structure and phylogeography of the lined shore crab, Pachygrapsus crassipes, along the northeastern and western Pacific coasts. Marine Biology, 149: 213-226. doi: 10.1007/s00227-005-0197-9

Clement, M., Posada, D.C.K.A. \& Crandall, K.A. 2002. TCS: estimating gene genealogies. Proceedings of the $16^{\text {th }}$ International Parallel and Distributed Processing Symposium, 2: 184.

Costlow, Jr., J.D. \& Bookhout, C.G. 1968. The effect of environmental factors on development of the landgrab, Cardisoma guanhumi Latreille. American Zoologist, 8: 399-410. doi: 10.1093/icb/8.3.399

Cowen, R.K. \& Sponaugle, S. 2009. Larval dispersal and marine population connectivity. Annual Review of Marine Science, 1: 443-466. doi: 10.1146/annurev. marine.010908.163757
De la Lanza-Espino, G. \& Montes, H.L. 1999. Comparación fisicoquímica de las lagunas de Alvarado y Términos. Hidrobiológica, 9: 15-30.

Diniz, F.M., Maclean, N., Ogawa, M., Cintra, I.H. \& Bentzen, P. 2005. The hypervariable domain of the mitochondrial control region in Atlantic spiny lobsters and it's potential as a marker for investigating phylogeographic structuring. Marine Biotechnology, 7: 462-473. doi: 10.1007/s10126-004-4062-5

Diario Oficial de la Federación (DOF). 2008. Programa rector nacional de pesca y acuacultura, Región III, ficha cangrejo semiterrestre. Secretaría de Gobernación, Mexico, D.F.

Diario Oficial de la Federación (DOF). 2010. Norma Oficial Mexicana NOM-059-ECOL-2001. Protección ambiental. Especies nativas de México de flora y fauna silvestres. Categorías de riesgo y especificaciones para su inclusión, exclusión o cambio. Lista de especies en riesgo. Secretaría de Gobernación, México, D.F.

Diario Oficial de la Federación (DOF). 2012. Carta nacional pesquera - ficha cangrejos semiterrestres. Secretaría de Gobernación, México, D.F.

Diário Oficial da União, Brazil (DOU). 2004. Instrução Normativa MMA no 5 de 21/05/2004. Lista Nacional das espécies de invertebrados aquáticos e peixes sobreexplotadas ou ameaçadas de sobreexplotação. Instrução normativa no. 5, 21 de maio de 2004. [http://www.prpe.mpf.mp.br/internet/content/downlo ad/2830/22487/file/in052004mma.pdf]. Reviewed: September 10, 2019.

Excoffier, L. \& Lischer, H.E. 2010. Arlequin suite ver 3.5: a new series of programs to perform population genetics analyses under Linux and Windows. Molecular Ecology Resources, 10: 564-567. doi: 10.1111/ j.1755-0998.2010.02847.x

Folmer, O., Black, M., Hoeh, W., Lutz, R. \& Vrijenhoek, R. 1994. DNA. primers for amplification of mitochondrial cytochrome c oxidase subunit I from diverse metazoan invertebrates. Molecular Marine Biology and Biotechnology, 3: 294-299.

Frankham, R., Briscoe, D.A. \& Ballou, J.D. 2002. Introduction to conservation genetics. Cambridge University Press, Cambridge. doi: 10.1017/CBO978 0511808999

Fratin, S. \& Vannini, M. 2002. Genetic differentiation in the mud crab Scylla serrata (Decapoda: Portunidae) within the Indian Ocean. Journal of Experimental Marine Biology and Ecology, 272: 103-116. doi: 10.1016/S0022-0981(02)00052-7

Florida Fish and Wildlife Conservation Commission (FWC). [http://myfwc.com]. Reviewed: September 10, 2019.

Grant, W.A.S. \& Bowen, B.W. 1998. Shallow population histories in deep evolutionary lineages of marine 
fishes: insights from sardines and anchovies and lessons for conservation. Journal of Heredity, 89: 415426. doi: 10.1093/jhered/89.5.415

Hartnoll, R.G. 1988. Evolution, systematic, and geographical distribution. In: Burggren, W.W. \& Mcmahon, B.B. (Eds.). Biology of the land crabs. Cambridge University Press, Cambridge, pp. 6-53.

Hostetler, M.E., Mazzotti, F.J. \& Taylor, A.K. 2003. Blue land crab (Cardisoma guanhumi). Institute of Food and Agricultural Sciences, University of Florida, Florida.

Kumar, G., Kunal, S.P., Menezes, M.R. \& Meena, R.M. 2012. Single genetic stock of kawakawa Euthynnus affinis (Cantor, 1849) along the Indian coast inferred from sequence analyses of mitochondrial D.N.A. Dloop region. Conservation Genetics, 13: 1119-1131. doi: 10.1007/s10592-012-0359-5

Lankford, R.R. 1977. Coastal lagoons of México. Their origin and classification. In: Wiley, M. (Ed.). Estuarine processes. Academic Press, Cambridge, pp. 182-215.

Librado, P. \& Rozas, J. 2009. DnaSP v5: a software for comprehensive analysis of D.N.A. polymorphism data. Bioinformatics, 25: 1451-1452. doi: 10.1093/ bioinformatics/btp187

Manzanilla-Dominguez, H. \& Gasca, R. 2004. Distribution and abundance of phyllosoma larvae (Decapoda, Palinuridae) in the southern Gulf of Mexico and the western Caribbean Sea. Crustaceana, 77: 75-93. doi: 10.1163/156854004323037900

McConaughey, J.R. 1992. Decapod larvae: dispersal, mortality, and ecology. A working hypothesis. American Zoologist, 32: 512-523. doi: 10.1093/icb/32.3. 512

McMillen-Jackson, A.L. \& Bert, T.M. 2004. Genetic diversity in the mtDNA control region and population structure in the pink shrimp Farfantepenaeus duorarum. Journal of Crustacean Biology, 24: 101109. doi: 10.1651/C-2372

Mims, M.C., Hauser, L., Goldberg, C.S. \& Olden, J.D. 2016. Genetic differentiation, isolation-by-distance, and metapopulation dynamics of the Arizona treefrog (Hyla wrightorum) in an isolated portion of its range. Plos One, 11: e0160655. doi: 10.1371/journal.pone. 0160655

Müller, K., Müller, J., Neinhui, C. \& Quandt, D. 2008. PhyDE - Phylogenetic data editor, Version 0.9971. [http://www.phyde.de]. Reviewed: July 12, 2019.

Naro-Maciel, E., Reid, B., Holmes, K.E., Brumbaugh, M.D.R., Artin, M. \& Desalle, R. 2011. Mitochondrial D.N.A. sequence variation in spiny lobsters: population expansion, panmixia, and divergence. Marine Biology, 158: 2027-2041. doi: 10.1007/ s00227-011-1710-y
Nei, M. 1987. Molecular evolutionary genetics. Columbia University Press, New York.

Oliva-Rivera, J.J. 2005. El cangrejo terrestre Cardisoma guanhumi ¿un recurso pesquero? Ecofronteras, 25: 1517.

Oliveira-Neto, J.F., Pie, M.R., Chammas, M.A., Ostrensky, A. \& Boeger, W.A. 2008. Phylogeography of the blue land crab, Cardisoma guanhumi (Decapoda: Gecarcinidae) along the Brazilian coast. Journal of the Marine Biological Association of the United Kingdom, 88: 1417-1423. doi: 10.1017/ S0025315408001999

Pfeiler, E., Hurtado, L.A., Knowles, L.L., Torre, J., Bourillón-Moreno, L., Márquez-Farías, J.F. \& Montemayor-López, G. 2005. Population genetics of the swimming crab Callinectes bellicosus (Brachyura: Portunidae) from the eastern Pacific Ocean. Marine Biology, 146: 559-569. doi: 10.1007/s00227-0041463-y

Pierce, J.C., Tan, G. \& Gaffney, P.M. 2000. Delaware Bay and Chesapeake Bay populations of the horseshoe crab Limulus polyphemus are genetically distinct. Estuaries, 23: 690-698. doi: 10.2307/1352895

Portilla-Ochoa, E., Sánchez-Hernández, A.I., OrtegaArgueta, A., Juárez-Eusebio, A., Escobar-López, H.E., Gutiérrez-García, R. \& García-Hernández, C. 2003. Establecimiento de unidades de gestión ambiental en el Humedal de Alvarado, Veracruz, México: base para su ordenamiento ecológico y social. Reporte académico semestral North American Wetlands Conservation Council (NAWCC). Área Biología de la Conservación. Instituto de Investigaciones Biológicas. Universidad Veracruzana, Veracruz.

Roman, J.O.E. \& Palumbi, S.R. 2004. A global invader at home: population structure of the green crab, Carcinus maenas, in Europe. Molecular Ecology, 13: 28912898. doi: 10.1111/j.1365-294X.2004.02255.x

Rozas, J. 2009. DNA sequence polymorphism analysis using DnaSP. In: Posada, D. (Ed.). Bioinformatics for DNA sequence analysis. Methods in molecular biology (methods and protocols). Vol. 537. Humana Press, New Jersey. doi: 10.1007/978-1-59745-251-9_17

Sánchez, A.J. \& Soto, L.A. 1993. Distribución de camarones inmaduros (Decapoda: Penaeidae) en el sistema lagunar de Alvarado, Veracruz, México. Revista de Biología Tropical, 41: 81-88.

Shanks, A., Grantham, B.A. \& Carr, M.H. 2003. Propagule dispersal distance and the size and spacing of marine reserves. Ecological Applications, 13: 159169.

Silva, C.C., Schwamborn, R. \& Oliveira, J.E. 2014. Population biology and color patterns of the blue land 
crab, Cardisoma guanhumi (Latreille 1828) (Crustacea: Gecarcinidae) in northeastern Brazil. Brazilian Journal of Biology, 74: 949-958. doi: 10.1590/15196984.01913

Spivak, E.D. 1997. Cangrejos estuariales del Atlántico sudoccidental $\left(25^{\circ}-41^{\circ} \mathrm{S}\right)$ (Crustacea: Decapoda: Brachyura). Investigaciones Marinas, 25: 105-120. doi: 10.4067/S0717-71781997002500008

Tajima, F. 1989. Statistical method for testing the neutral mutation hypothesis by D.N.A. polymorphism. Genetics 123: 585-95.

Weersing, K. \& Toonen, R.J. 2009. Population genetics, larval dispersal, and connectivity in marine systems. Marine Ecology Progress Series 393: 1-12. doi: 10.3354/meps08287

Received: 3 December 2019; Accepted: 8 October 2020
Weinberg, J.R., Dahlgren, T.G., Trowbridge, N. \& Halanych, K.M. 2003. Genetic differences within and between species of deep-sea crabs (Chaceon) from the North Atlantic Ocean. Biological Bulletin, 204: 318326. doi: $10.2307 / 1543602$

Yuhara, T., Kawane, M. \& Furota, T. 2014. Genetic population structure of local populations of the endangered saltmarsh sesarmid crab Clistocoeloma sinense in Japan. Plos One, 9: e84720. doi: 10.1371/journal.pone.0084720

Zavala-Hidalgo, J., Morey, S.L. \& O'Brien, J.J. 2003. Seasonal circulation on the western shelf of the Gulf of Mexico using a high-resolution numerical model. Journal of Geophysical Research: Oceans, 108: 3389. doi: 10.1029/2003JC001879

Table Supplementary 1. Distribution and frequency of analyzed COI haplotypes in this study for Cardisoma guanhumi $(\mathrm{n}=70)$.

\begin{tabular}{|c|c|c|c|c|}
\hline Haplotype & Frequency & $\begin{array}{l}\text { Relative } \\
\text { frequency }\end{array}$ & Samples & $\begin{array}{c}\text { Genbank accession } \\
\text { number }\end{array}$ \\
\hline $\mathrm{Cg}-\mathrm{COI}-\mathrm{HI}$ & 2 & 0.029 & 1,56 & MF583047 \\
\hline $\mathrm{Cg}-\mathrm{COI}-\mathrm{H} 2$ & 7 & 0.100 & $2,6,15,30,51,63,69$ & MF583048 \\
\hline $\mathrm{Cg}-\mathrm{COI}-\mathrm{H} 3$ & 8 & 0.114 & $3,24,40,44,46,57,71,77$ & MF583049 \\
\hline $\mathrm{Cg}-\mathrm{COI}-\mathrm{H} 4$ & 15 & 0.214 & $\begin{array}{c}4,16,17,25,26,28,33,41 \\
45,49,58,60,73,75,76\end{array}$ & MF583050 \\
\hline $\mathrm{Cg}-\mathrm{COI}-\mathrm{H} 5$ & 1 & 0.014 & 5 & MF583051 \\
\hline $\mathrm{Cg}$-COI-H6 & 2 & 0.029 & 7,47 & MF583052 \\
\hline $\mathrm{Cg}-\mathrm{COI}-\mathrm{H} 7$ & 7 & 0.100 & $9,34,35,39,62,67,68$ & MF583053 \\
\hline $\mathrm{Cg}-\mathrm{COI}-\mathrm{H} 8$ & 1 & 0.014 & 11 & MF583054 \\
\hline $\mathrm{Cg}-\mathrm{COI}-\mathrm{H} 9$ & 2 & 0.029 & 12,80 & MF583055 \\
\hline $\mathrm{Cg}-\mathrm{COI}-\mathrm{H} 1 \mathrm{O}$ & 3 & 0.043 & $13,37,70$ & MF583056 \\
\hline $\mathrm{Cg}-\mathrm{COI}-\mathrm{HII}$ & 1 & 0.014 & 14 & MF583057 \\
\hline $\mathrm{Cg}-\mathrm{COI}-\mathrm{H} 12$ & 1 & 0.014 & 22 & MF583058 \\
\hline $\mathrm{Cg}-\mathrm{COI}-\mathrm{H} 13$ & 1 & 0.014 & 23 & MF583059 \\
\hline $\mathrm{Cg}-\mathrm{COI}-\mathrm{HI} 4$ & 2 & 0.029 & 27,55 & MF583060 \\
\hline $\mathrm{Cg}-\mathrm{COI}-\mathrm{H} 15$ & 2 & 0.029 & 36,48 & MF503061 \\
\hline $\mathrm{Cg}-\mathrm{COI}-\mathrm{H} 16$ & 3 & 0.043 & $38,59,66$ & MF583062 \\
\hline $\mathrm{Cg}-\mathrm{COI}-\mathrm{H} \mathrm{I7}$ & 2 & 0.029 & 42,72 & MF583063 \\
\hline $\mathrm{Cg}-\mathrm{COI}-\mathrm{H} 18$ & 1 & 0.014 & 43 & MF583064 \\
\hline Cg-COI-H19 & 1 & 0.014 & 50 & MF583065 \\
\hline $\mathrm{Cg}-\mathrm{COI}-\mathrm{H} 2 \mathrm{O}$ & 1 & 0.014 & 52 & MF583066 \\
\hline $\mathrm{Cg}-\mathrm{COI}-\mathrm{H} 2 \mathrm{I}$ & 1 & 0.014 & 53 & MF583067 \\
\hline $\mathrm{Cg}-\mathrm{COI}-\mathrm{H} 22$ & 1 & 0.014 & 61 & MF583068 \\
\hline $\mathrm{Cg}-\mathrm{COI}-\mathrm{H} 23$ & 1 & 0.014 & 64 & MF583069 \\
\hline $\mathrm{Cg}-\mathrm{COI}-\mathrm{H} 24$ & 1 & 0.014 & 65 & MF583070 \\
\hline $\mathrm{Cg}-\mathrm{COI}-\mathrm{H} 25$ & 1 & 0.014 & 74 & MF583071 \\
\hline $\mathrm{Cg}-\mathrm{COI}-\mathrm{H} 26$ & 1 & 0.014 & 78 & MF583072 \\
\hline $\mathrm{Cg}-\mathrm{COI}-\mathrm{H} 27$ & 1 & 0.014 & 79 & MF583073 \\
\hline
\end{tabular}


Table Supplementary 2. Distribution and frequency of analyzed partial mitochondrial control region mtDNA in this study, for Cardisoma guanhumi $(\mathrm{n}=58)$.

\begin{tabular}{lcccc}
\hline Haplotype & Frequency & $\begin{array}{c}\text { Relative } \\
\text { frequency }\end{array}$ & Samples & $\begin{array}{c}\text { Genbank accession } \\
\text { number }\end{array}$ \\
\hline Cg-Dloop-H1 & 22 & 0.37 & $1,4,8,10,13,16,21,25,39,42,48,4$ & MF583074 \\
Cg-Dloop-H2 & 4 & 0.06 & $9,52,56,57,58,60,67,68,70,73,78$ & \\
Cg-Dloop-H3 & 6 & 0.10 & $2,50,63,64$ & MF583075 \\
Cg-Dloop-H4 & 2 & 0.03 & $3,23,31,44,54,71$ & MF583076 \\
Cg-Dloop-H5 & 2 & 0.03 & 6,41 & MF583077 \\
Cg-Dloop-H6 & 4 & 0.06 & 7,53 & MF583078 \\
Cg-Dloop-H7 & 2 & 0.03 & $9,11,51,69$ & MF583079 \\
Cg-Dloop-H8 & 1 & 0.01 & 14,22 & MF583080 \\
Cg-Dloop-H9 & 1 & 0.01 & 15 & MF583082 \\
Cg-Dloop-H10 & 7 & 0.12 & 18 & MF583083 \\
Cg-Dloop-H11 & 1 & 0.01 & $26,27,28,45,55,61,66$ & MF583084 \\
Cg-Dloop-H12 & 1 & 0.01 & 34 & MF583085 \\
Cg-Dloop-H13 & 1 & 0.01 & 43 & MF583087 \\
Cg-Dloop-H14 & 1 & 0.01 & 47 & MF583088 \\
Cg-Dloop-H15 & 1 & 0.01 & 59 & MF583089 \\
Cg-Dloop-H16 & 1 & 0.01 & 62 & MF583090 \\
Cg-Dloop-H17 & 1 & 0.01 & 65 & \\
\hline
\end{tabular}

